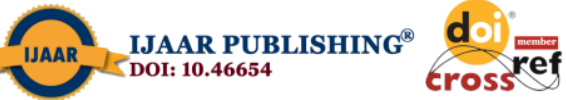

International Journal of Advanced Academic Research (Arts, Humanities and Education) | ISSN: 2488-9849

Vol. 6, Issue 10 (October, 2020)|www.ijaar.org

Journal DOI: 10.46654/ij.24889849

Article DOI: 10.46654/ij.24889849.a61011

\title{
ASSESSMENT OF THE IMPACT OF TRANSFORMATIONAL LEADERSHIP STYLE ON STUDENTS' ACADEMIC ACHIEVEMENT IN ENGLISH LANGUAGE
}

\author{
Dr. Ogbonnaya, C.N; Dr. Izuagba, J.N \& Chukwudebelu, C.B \\ Department of Educational Foundations \& Administration \\ Alvan Ikoku Federal College of Education, Owerri \\ Phone: +2347030164247 \\ Email: ogbonnayacomfort29@gmail.com
}

\begin{abstract}
This study investigated impact of transformational leadership style on students' academic achievement in English language Owerri Municipal Council of Imo State. Based on the purpose of the study, one research question guided the study. Descriptive survey design was adopted for the study. The population of the study comprised all 18 Principals and 1, 267 SS2 students. The instruments used for data collection were transformational leadership style questionnaire adapted and developed by Leithwood and Jantzi (1999) and English language Achievement Test (ELAT). The validity of the instruments was done by two experts in Measurement and Evaluation and one expert in Educational Foundation and Administration. The reliability of the instruments was 0.93 and 0.90, determined using Cronbach Alpha and Pearson Product Moment Correlation (PPMC) statistics. Data collected were analyzed using correlations. Thus, it concludes that, transformational leadership styles have positive relationship with student's academic achievement.
\end{abstract}

Keywords: Transformational Leadership Style and Academic Performance 


\section{Introduction}

Education play important role with the intension to make teaching and learning more effective and to give quality education to students. It is the bedrock of national development as well a catalyst to sustainable development. Also, it is a process whereby skills, knowledge, attitude, and virtues are inculcated in individuals. Most educational experts consider administrators as the driving force and main source of the organizational development and academic growth of students (Mirkamali, 1995). The successes of an administrator have been the various methods used in their administration process. The administrator's leadership style influences the efficiency and also the effectiveness of the organization. There are different types of leadership styles but the interest of the researchers is on transformational leadership style.

Transformational leadership can be defined as increasing the interest of the workers to achieve higher performance through developing the commitments and beliefs in the organization (Bass, 1985). It entails moving people to a common vision by building trust and empowerment (Carlson, 1996). Transformational leaders are motivating, influential, and proactive. They optimize people's development and innovation and convince them to strive for higher levels of achievement (Avolio \& Bass, 2004). According to Burns (1978), transformational leaders form a relationship of mutual stimulation and elevation that converts followers into leaders. Daft (2008) defined transformational leadership as characterized by the ability to bring about significant change in followers and the organization. Transformational leadership is conceptualized as involving a series of behaviours designed to inspire, empower, and motivate others to achieve higher levels of goals and missions (Avolio \& Bass, 2004; Hunt, 1999).Specifically, transformational leadership can be carried out by providing clear and compelling goals (Kim, 2010), displaying as a role model and motivating followers to accomplish the goals. Bass (1985) introduced four dimensions of transformational leadership styles: idealized influence, inspirational motivation, intellectual stimulation, and individual consideration. The description below provides more in-depth information about each dimension.

Idealized influence. Idealized influence implies that followers consider their leaders as role models who practice ethical conduct that inspires respect and trust (Barling, Christie, \& Hoption, 2010).Transformational leaders resist pressures of immoral and unethical behaviors, by demonstrating highly ethical behavior and extensive personal rapport such as respect, trust, honesty, dignity, enthusiasm, responsibility and influencing positive behaviors, the transformational leader is able to instill critical life virtues into followers.

Inspirational motivation. Inspirational motivation takes place when leaders share a vision and goal with the organization and followers (Pounder, 2003). Transformational leaders identify and set clear visions and realistic goals as they relate to followers' goals and enthusiasm (Bass \& Avolio, 1994). This can be done by communicating clearly with followers, and encouraging and supporting them.

Intellectual stimulation. Intellectual stimulation involves promoting followers' curiosity, problem-solving, and novel ways of thinking by stimulating followers' intelligence. According to Daft (2014), "people admire leaders who awaken their curiosity, challenge them to think and learn, and encourage openness to new, inspiring ideas and alternatives. Transformational leaders 
recognize all types of issues and problems and help followers to solve problems in creative and innovative ways.

Individualized consideration. Individualized consideration takes place when leaders seek and respond to followers' specific needs and capabilities (Bass \& Avolio, 1994). By listening and caring about followers' concerns and issues, transformational leaders should be able to help and support properly (Avolio \& Bass, 1998). Being effective communicators implies multiple important aspects, such as skill in building an intimate relationship, and listening and providing proper reinforcement.

Hence, there is need to establish whether modern leadership styles and in particular transformational leadership style may assist to alleviate the problem of low academic achievement especially English language. Waithiegeni (2013) notes that the performance of the children greatly depends on various factors which vary from one school to another depending on the dynamics. Top on the list of these factors is leadership styles of the school administrators of such schools. Nyaboga (2011) agrees with this observation by noting that good performance in school's achievement is relatively equivalent to good administration.

According to Eshiwani (1983), schools which consistently perform well in English language tend to have sound and efficient leadership. He further stresses that leadership is a crucial factor in the success of all the school activities and in particular to student's academic achievement. Uwezo (2013) observes that despite using a variety of aspects to determine pupils' academic achievement at the primary schools, academic achievement still carries more weight because the education system is more of academic oriented instead of considering other aspects that are more practical. However, despite the importance of education to nation building, students' academic achievement at the primary school level has been below expectations. Some of the factors that have contributed to this low academic achievement include; Leadership styles, lack of cooperation by the stakeholders, social background of the children and pupils' indiscipline.

Research on this study gives mixed results. On the one hand, there are studies which confirm the existence of a relationship between transformational leadership style and students' performance. For example, Ubben and Hughes (1992) found that leadership improves the productivity of both teachers; students can foster good academic performance. Hallinger and Heck (1998) reviewed over 40 empirical studies conducted between 1980 and 1995 and concluded that principals exercised a measurable and statistically significant, though small, indirect impact on school effectiveness and student achievement.

Similarly, Witziers, Bosker, and Kruger (2003) found that school leadership has a positive influence on student achievement and Waters, Marzano, and McNulty (2004) reported that effective transformational leadership style substantially increases student achievement.

Kruger, Witziers, and Sleegers (2007) found that school leaders indirectly influence student outcomes. In the context of Cyprus, Kythreotis and Pashiardis (2006), it was found that principal's transformational leadership style enhances student achievement in English language. Avolio's (1994) and Huffman (2003) found positive relationship between leadership styles 
(transformational) and student's achievement. Di Vincenzo's (2008) investigated transformational leadership behaviours of principals and student achievement. He found no statistically significant correlation relationship between the leaders' attributes. Using Bass and Avolio's (1994) Multifactor Leadership Questionnaire, Huffman (2003) found no relationship between leadership styles (transformational) and improved student achievement. It was concluded, however, that transformational leadership was related to increased students' achievement and teachers' job performance.

Azam and Natyada (2012) study conducted in private religious schools; South Thailand found that there is a positive relationship between transformational leadership and academic performance. The findings of Kappen (2010) found that transformational leadership has a positive contribution with motivation and there was a positive relationship with intrinsic motivation.

Research into gender leadership styles has found that women are slightly stronger in relationship-oriented supportive styles, while men score higher in transformational leadership styles (Fennell, 2005; Kruger 1996, 2008). Eagly, Johannesen-Schmidt, and Van Engen (2003), for example, offered a quantitative synthesis of 45studies on transformational leadership comparing women and men. They found that women scored higher than men in transformational leadership and moreover, women produced considerably better outcomes than men on all of the three outcome measures that the Multifactor Leadership Questionnaire investigated.

Kent, Blair, Rudd and Schuele (2010) found no difference in transformational leadership practices among transformational leaders. Balasubramanian and Krishnan (2012) found that women bank managers in India are more practicing transformational leadership than male managers. Kythreotis and Pashiardis (2006) also found that female school principals showed transformational leadership style than male school principals. They argue that interpersonal relations constitute a more central point of reference of the managerial style of women and allow them to exhibit a more democratic and participative style (Coleman, 1998). Therefore, the study intends to investigate the impact of transformational leadership styles and pupils' academic achievement.

\section{Purpose of the Study}

The main purpose of the study is to examine the relationship between transformational leadership style on students' academic achievement in English language. Specifically, it seeks;

(i) To establish the relationship between transformational leadership style and students' academic achievement in English Language.

\section{Hypotheses}

1. There is no significant relationship between idealized influence leadership style and students' academic achievement in English Language.

2. There is no significant relationship between inspirational motivation leadership style and students' academic achievement in English Language. 
3. There is no significant relationship between intellectual stimulation leadership style and students' academic achievement in English Language.

4. There is no significant relationship between individualized consideration leadership style and students' academic achievement in English Language.

\section{Methodology}

The research design adopted for this study is the correlational survey method. This design was considered suitable for the study because it gives the researchers the opportunity of obtaining the opinion of the sampled population to infer the opinion of the entire population. The population of the study comprised all 18 Principals and 1, 267 SS2 students in Owerri Municipal Council Area of Imo State. A sample size of 18 school headmistress and 105 pupils were used for the study using simple random sampling techniques in selecting the pupils. The instruments used for data collection are transformational leadership styles questionnaire (TLQ) adapted by Anandan (2011) and developed by Leithwood and Jantzi (1999) containing 34 items were used to measure the transformational leadership styles and students' Performance Scores in English language (PPEL) for 2018/2019 academic sessions was used in obtaining relevant data for the study. The questionnaire items were face-validated to ascertain its suitability for use in data collection by two experts in educational foundations and Administration and one expert in Measurement and evaluation education. The language, contents and the structure of the items were critically examined and possible corrections and suggestions were made. The reliability of the instrument was ascertained using a Cronbach- Alpha method. The reliability co-efficient of 0.93 and 0.90 was obtained respectively for the instruments and was adjudged good and reliable for the study. Data collected were analyzed using Pearson product moment correlation at 00.5 level of significant.

\section{Results}

HO1: There is no significant relationship between idealized influence leadership style and pupils' academic achievement in English Language.

Table 1: Correlation Analysis on idealized influence leadership style and pupils' Academic Achievement in English language

\begin{tabular}{llll}
\hline VARIABLES & $\mathrm{N}$ & $\mathrm{R}$ & sig \\
\hline IDEALIZED INFLUENCE & 40 & $\mathbf{0 . 6 5}$ & $\mathbf{0 . 0 0 0}$ \\
LEADERSHIP STYLE & & & \\
ENGLISH LANG. & & & \\
ACHIEVEMENT & & &
\end{tabular}

Results in the table one revealed that there is a positive relationship between idealized influence leadership style and pupils' academic achievement in English Language ( $\mathrm{r}=0.65, \mathrm{P}<$ $0.05)$. 
Journal DOI: 10.46654/ij.24889849

Vol. 6, Issue 10 (October, 2020) | www.ijaar.org

Article DOI: 10.46654/ij.24889849.a61011

HO2: There is no significant relationship between inspirational motivation leadership styles and pupils' academic achievement in English Language.

Table 2. Correlation analysis on inspirational motivation leadership style and pupils' academic achievement in English Language.

\begin{tabular}{llll}
\hline VARIABLES & N & R & sig \\
\hline INSPIRATIONAL MOTIVATION & 40 & 0.72 & $\mathbf{0 . 0 0 0}$ \\
LEADERSHIP STYLE & & & \\
ENGLISH LANG. & & & \\
ACHIEVEMENT & & & \\
\hline
\end{tabular}

Results in the table 2 revealed that there is a positive relationship between inspirational motivation leadership styles and pupils' academic achievement in English Language ( $\mathrm{r}=0.72, \mathrm{P}$ $<0.05)$.

HO3: There is no significant relationship between intellectual stimulation leadership style and pupils' academic achievement in English Language.

Table 3. Correlation analysis on intellectual stimulation leadership style and pupils' academic achievement in English Language

\begin{tabular}{llll}
\hline VARIABLES & N & R & sig \\
\hline INTELLECTUAL & 40 & 0.59 & 0.000 \\
STIMULATION LEADERSHIP & & & \\
STYLE & & & \\
ENGLISH LANG & & & \\
ACHIEVEMENT & & & \\
\hline
\end{tabular}

Results in the table 3 revealed that there is a positive relationship between intellectual stimulation leadership style and pupils' academic achievement in English Language ( $\mathrm{r}=0.59 ; \mathrm{P}$ $<0.05)$. 
HO4: There is no significant relationship between individualized consideration leadership style and pupils' academic achievement in English Language.

Table 4. Correlation analysis on individualized consideration leadership style and pupils' academic achievement in English Language

\begin{tabular}{llll}
\hline VARIABLES & $\mathrm{N}$ & $\mathrm{R}$ & $\mathrm{sig}$ \\
\hline INDIVIDUALIZED & 40 & $\mathbf{0 . 7 0}$ & $\mathbf{0 . 0 0 0}$ \\
CONSIDERATION & & & \\
LEADERSHIP STYLES & & & \\
ENGLISH LANG & & & \\
ACHIEVEMENT & & & \\
\hline
\end{tabular}

Results in the table 4 revealed that there is a positive relationship between intellectual stimulation leadership style and pupils' academic achievement in English Language ( $r=0.70 ; \mathrm{P}$ $<0.05)$.

\section{Discussion}

The study showed that the relationship between transformation leadership styles and pupils' academic achievement in English language is positive significant relationship. School leaders have high level of practices in transformational leadership styles and whenever the school principals employed a leadership style there was bound to be a direct response in relation to the students and teachers. The findings of this study supported the study of Azam and Natyada (2012) conducted in private religious schools; South Thailand which found that there is a positive relationship between transformational leadership and academic performance. The findings of Kappen (2010) found that transformational leadership has a positive contribution with motivation and there was a positive relationship with intrinsic motivation.

\section{CONCLUSION}

This study concludes that good teaching, providing effective leadership have positive impacts on students' academic achievements. The results of the study showed that transformational leadership has positive relationship with students' academic achievement. Thus, it concludes that, school principals showed high level of practices in transformational leadership styles.

\section{Recommendations}

Based on these findings, the following recommendations are made for this study;

1. School principals need to be sensitized on the importance on adopting modern management styles and in particular transformational leadership style.

2. The Ministry of Education should provide adequate teaching and learning resources in order to support the implementation of transformational leadership style in secondary schools. 


\section{References}

Avolio, B. (1999). Full leadership development: Building the vital forces in organizations. Thousand Oaks, CA: Sage.

Avolio, B. J., \& Bass, B. M. (2004). Multifactor leadership questionnaire: Third edition manual and sampler set. Redwood City, CA: Mind Garden.

Balasubramanian, P., \& Krishnan, V.R. (2012). Impact of gender and transformational leadership on ethical behaviors. Great Lakes Herald, 6(1), 48-58.

Barling, J., Christie, A., \& Hoption, A. (2010). Leadership. In S. Zedeck (Ed.),Handbook of industrial and organizational psychology (pp. 183-240). Washington, DC: American Psychological Association.

Bass, B. (1985). Leadership and performance beyond expectations. New York: The Free Press.

Bass, B.M., \& Avolio, B.J. (1994). Improving organizational effectiveness through transformational leadership. Sage.

Burns, J. M. (1978). Leadership. NY: Harper \& Row.

Carlson, R. (1996). Reframing and reform: Perspectives on organization, leadership, and school change. White Plains, NY: Longman.

Coleman, M. (1998). The management style of female head-teachers. Educational Management andAdministration, 24(2), 163-16.

Di Vincenzo, R. (2008). School leadership and its relation to school performance. Unpublished Dissertation: University of Phoenix. ProQuest, 3323345.

Eagly, A.H., Johannesen-Schmidt, M.C., \& Van Engen, M.L. (2003). Transformational, transactional, and laissez-faire leadership styles: A meta-analysis comparing men and women. Psychological Bulletin, 129,569-591. http://dx.doi.org/10.1037/00332909.129.4.569.

Eshiwani, G. S. (1983). Factors Influencing Performance among Primary and Secondary Schools in Western Province. Policy Study (Kenyatta University College). Bureau of Educational Research.

Fennell, H. (2005). Living leadership in an era of change. International Journal of Leadership in Education, 8(2),145-165. http://dx.doi.org/10.1080/1360312042000270487.

Hallinger, P., \& Heck, R. (1998). Exploring the principal's contribution to school effectiveness: 1980-1995.School Effectiveness and School Improvement, 9(2), 157191.http://dx.doi.org/10.1080/0924345980090203. 
Huffman, N. (2003). The relationship of principal leadership style and student achievement in low-socioeconomic schools. Unpublished Doctoral dissertation, Purdue University. ProQuest 3113852 Kruger, M. (1996). Gender issues in school headship: quality versus power? European Journal of Education,31(4), 447-461.

Kappen, F. (2010). Leadership and motivation: How leadership-styles contribute to employees' intrinsic and extrinsic motivation. (Unpublished bachelor's degree thesis). Tilburg University

Kent, T.W., Blair, C.A., Rudd, H.F., \& Schuele, U. (2010). Gender differences and transformational leadership behavior: Do both German men and women lead in the same way. International Journal of Leadership Studies, 6(1), 52-66.

Kim, B.Y. (2010). Application of Transformational Leadership: The Case of Hiddink Leadership. The Korean Association of Sport Law, 13(1), 11-37.

Kirkbride, P. (2006). Developing transformational leaders: the full range leadership model in action, Industrial and commercial training, 38(1), 23-32.

Kouzes, J. (2003). The leadership practices inventory (LPI): Self-instrument (3rd ed.). San Francisco: Jossey-Bass.

Kruger, M. (1996). Gender issues in school headship: quality versus power? European Journal of Education, 31(4), 447-461.

Kruger, M., Witziers, B., \& Sleegers, P. (2007). The impact of school leader variables on school level factors: Validation of a causal model. School Effectiveness and School Improvement, 18(1), 1-20.http://dx.doi.org/10.1080/09243450600797638.

Kythreotis, A., \& Pashiardis, P. (2006). Exploring leadership role in school effectiveness and the validation of models of principals' effects on students' achievement. Paper presented at the Commonwealth Council for Educational Administration and Management (CCEAM) Conference 2006 "Recreating Linkages between Theory and Praxis in Educational Leadership", Nicosia: Cyprus Coleman, M. (1998). The management style of female headteachers. Educational Management and Administration, 24(2), 163-164.

Mirkamali .M. (1995) Educational management and publication: 1995.Leadership.Tehran:Ramin publications.

Nyaboga, N. E. (2011). Leadership Styles of Principals and their Impact On Students' Academic Performance In Secondary Schools, Nyamaiya Division, Nyamira District. Unpublished Thesis, Kenyatta University.

Pounder, J. S. (2003). Employing transformational leadership to enhance the quality of management development instruction. Journal of Management Development, 22, 6-13. Daft, R. L. (2008). The leadership experience (4th ed.). Mason, OH: SouthWestern. 
Journal DOI: 10.46654/ij.24889849

Vol. 6, Issue 10 (October, 2020) | www.ijaar.org

Ubben, G., \& Hughes, L. (1992). The principal: Creative leadership for effective schools. Meedham Heights,MA: Allyn and Bacon.

Uwezo. (2013). An Audit of the Education sector East Africa, UWEZO Education Trust, Nairobi,ISBN 9966-7026-9-5.

Waithiegeri, K. A. (2013). The Challenges of Leading Public Schools in Kenya: London; Oxford University Press. Bass, B. (1985). Leadership and performance beyond expectations. New York: The Free Press.

Waters. T., Marzano, R., \& McNulty, B. (2004). Leadership that sparks learning. Educational Leadership, 61(1), 48-52.

Waters. T., Marzano, R., \& McNulty, B. (2004). Leadership that sparks learning. Educational Leadership, 61(1),48-52.

Witziers, B., Bosker, R., \& Kruger, M. (2003). Educational leadership and student achievement: The elusivesearch for an association. Educational Administration Quarterly, 39(3), 398425.http://dx.doi.org/10.1177/0013161X03253411. 